Resenhas

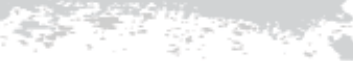

Rui Massato Harayama

(FSMES)

\section{BONET, Octavio. Os médicos da pessoa: Um olhar antropológico sobre a medicina de família no Brasil e na Argentina. I ed. - Rio de Janeiro: 7 letras, 2014. 266 pp.}

O livro de Octavio Bonet é resultado da tese de Doutorado do autor e propõe uma etnografia sobre a formação da especialidade 'medicina de família' em dois contextos nacionais diferentes, Brasil e Argentina. A formação dos médicos é tema clássico na antropologia e sociologia da saúde, com trabalhos que remetem aos clássicos da área como Boys in White, de Howard Becker, publicado em 1961. O próprio autor já tinha abordado a formação de médicos na Argentina, em seu mestrado.

Entretanto, nessa obra, a aposta do autor em trazer o método comparativo da etnografia para analisar os processos de institucionalização da medicina de família em dois contextos nacionais - o brasileiro e o argentino - é feliz em matizar um tema de pesquisa tão comum na saúde pública brasileira: o Programa Saúde da Família.

O rendimento etnográfico do autor mostra-se profícuo ao conseguir aliar múltiplos espaços de observação, o que ressalta a necessária e feliz atuação do antropólogo em contextos contemporâneos ao etnografar a institucionalização da especialidade por meio do acompanhamento nos centros e postos de saúde, das consultas, na lista de e-mails e nos congressos da área. Se a antropologia das sociedades complexas, do 'centro' ou up, é cada vez mais presente no Brasil, ela necessita de criações e invenções metodológicas para a investigação em espaços pouco comuns na literatura antropológica. Em se tratando da formação profissional dentro de um contexto ocidental, não se deve deixar de lado, como bem acompanha o autor, elementos poucos usuais de atenção etnográfica, como congressos, listas de e-mails e espaços de discussão. São nesses elementos que a pesquisa antropológica, fiel a uma tradição etnográfica, se difere das tradicionais pesquisas qualitativas na área da saúde.

Dentro da economia do texto, se as tradicionais entrevistas aparecem quase como ilusões biográficas, à la Bourdieu - para a invenção da vocação de um especialista no discurso dos entrevistados -, os congressos, as listas de e-mails e espaços de discussão são processos coletivos e constitutivos da formação identitária 
e epistemológica, e têm centralidade na investigação do autor, sobretudo se pensarmos na proposta de compreender a institucionalização desse processo de campo profissional para além da dicotomia entre 'teoria' e 'prática'. E nesse sentido, a intenção principal do autor é a de "ver como as práticas são guiadas por uma epistemologia determinada e como esta incide na sua definição de sua identidade profissional." (:44).

As diferenças entre a institucionalização da profissão na Argentina - onde a discussão centrava-se entre os grupos da medicina da família e dos generalistas - e no Brasil - com a disputa entre comunitaristas e os familiaristas - demonstram como as questões identitárias também são semânticas, sobretudo quando os grupos precisam lidar com o acaso, como foi a incidência de políticas governamentais de saúde pública que culminaram, no caso brasileiro, no Programa Saúde da Família.

A obra demonstra de forma detalhada como são as resoluções discutidas e definidas em instâncias internacionais, como a Conferência de Alma-Ata de 1978, que precisam ser negociadas e aclimatizadas em diferentes contextos nacionais. Nesse sentido, surge como nota de rodapé, mas de extremo interesse para pesquisas posteriores, a ação da Fundação Kellogs (:117) na formação de agentes para a promoção de saúde no Brasil. De fato, o autor demonstra o potencial da sua obra para a área dos estudos da saúde pública brasileira ao não replicar os argumentos recorrentes nas pesquisas que partem do princípio da Reforma Sanitária como elemento dado, ou muitas vezes mítico, a partir das quais as diferentes políticas e concepções de saúde surgem, incluindo a noção biopsicossocial escrutinada pelo autor no Capítulo 4. Esse capítulo traz à centralidade o dado etnográfico de que os médicos de família cada qual " constrói sua epistemologia; essa epistemologia será sua forma de estar no mundo, sua forma de estar na medicina, sua forma de fazer medicina" (:162).

Um dos diferenciais do saber-fazer dos médicos de família é a promoção da saúde, esse é o elemento constitutivo para a especialidade já que ela opera tencionando uma tênue linha que o autor propôs chamar, seguindo Le Breton, de ética da responsabilidade e ética da convicção. É essa dupla conceitual que demonstra a sensibilidade do autor em perceber a incerteza como importante operador nos atendimentos clínicos, ou ainda, a incerteza de quais elementos trazidos pelos pacientes que devem ser 'levados a sério' no momento do atendimento: sintomas biológicos, sociais ou subjetivos. Entretanto, a análise do autor parece sedimentada em um pressuposto de divisão entre objetivo e subjetivo. Ao analisar uma das consultas diz que "A epistemologia integral que guiava os passos de Maria lhe permitiu que, sem deixar de atender às questões somáticas, fundamentasse parte de suas decisões em uma leitura psicológica dos sintomas" (:175), nesse ponto o autor passa a tentar realizar diversas incursões etnográficas-explicativas de como se poderia compreender e elucidar a epistemologia da integralidade nos atendimentos acompanhados. Essa é, com certeza, a parte mais árida da obra. A integralidade entendida ora como o acolhimento das questões subjetivas, psicológicas, espirituais e sociais, vai sendo refinada em diversas aproximações, seja com explicações mais psicanalíticas até culturalistas. Entretanto, apesar do autor enunciar a versão de Ingold de "organismo no seu entorno" (:196) com o intuito de superar as cisões corpo, mente e cultura, a dicotomia reaparece na teorização do micro e macro-holismo proposta pelo autor. "O primeiro deles [o micro holismo] remeteria ao primeiro uso da noção de pessoa; o segundo holismo estaria voltado para a integração desta com os elementos constitutivos que excedem seus limites corporais e 
que apontam para o contexto do qual o indivíduo faz parte."(:183). Dessa forma, parece estar presente uma substituição de dicotomia biológico-cultural para um outro de escala, micro e macro.

Para os estudos da antropologia da saúde, a obra apresenta dados e reflexões importantes sobre como se institucionaliza e tenciona um campo de especialidade médica, mas reitera certos passos que poderiam ser matizados na pesquisa, sobretudo em observar como essa epistemologia integral, no seu cotidiano, é tencionada e criada não somente na relação com o paciente, mas no cotidiano com os demais profissionais dos serviços de saúde: onde estariam os outros atores que trabalham juntos com esses médicos?

As pistas para essa discussão parecem surgir dentro dos dados apresentados pelo próprio autor, como na discussão sobre a psicologização, que vira chave explicativa para diversos pontos, mas não apresenta debate mais aprofundado sobre a conceituação nativa do termo: a partir de quais experiências e conceituações eles trazem essa discussão? A psicologização é categoria êmica dos médicos ou do autor? Sem uma definição clara dos limites entre conceituações do autor e dos observados a concepção de alguns termos como 'culturas', 'psicologização' e 'medicalização' precisam ser completadas com os pressupostos do próprio leitor para que possam fazer sentido. 